九州大学学術情報リポジトリ

Kyushu University Institutional Repository

\title{
Mesocotyl Elongation in Rice Seedlings Grown from Immature Grains
}

Inouye, Jun

Laboratory of Crop Science, Faculty of Agriculture, Kyushu University

Terao, Hiroyuki

Laboratory of Crop Science, Faculty of Agriculture, Kyushu University

Oritani, Takashi

Laboratory of Crop Science, Faculty of Agriculture, Kyushu University

Ito, Kenji

Laboratory of Crop Science, Faculty of Agriculture, Kyushu University

https://doi.org/10.5109/22837

出版情報：九州大学大学院農学研究院紀要. 17 (3/4)，pp.283-287，1973-10. Kyushu University バージョン：

権利関係 : 
J. Fac. Agr., Kyushu Univ., 17, 283-287 (1973)

\title{
Mesocotyl Elongation in Rice Seedlings Grown from Immature Grains
}

\author{
Jun Inouye, Hiroyuki Terao, Takashi Oritani* and Kenji Ito \\ Laboratory of Crop Science, Faculty of Agriculture, \\ Kyushu University, Fukuoka
}

(Received May 30, 1973)

\begin{abstract}
In three cultivars of japonica paddy rice, mesocotyl length of seedlings grown in the dark from grains obtained 10 and 20 days after anthesis was greater than $10 \mathrm{~mm}$, while mesocotyl length decreased with the maturity of the grain and it was less than $10 \mathrm{~mm}$ in grain obtained 40 days after anthesis. Abscisic acid (ABA) stimulated the elongation of mesocotyl to more than $10 \mathrm{~mm}$ in a cultivar of japonica paddy rice in the dark, though it inhibited the elongation of coleoptile. It seems that morphological characters of these seedlings were similar to those of the seedlings grown from immature grains. From the above results, it is suggested that ABA-like substances were contained in the mesocotyl of the paddy rice seedlings grown from immature grains.
\end{abstract}

\section{INTRODUCTION}

The sativa rice varieties of the world were firstly grouped by Kato and coworkers $(1928,1930)$ into japonica and indica sub-species on the basis of morphological differences, serological reactions and sexual affinities.

According to Hamada (1937), the mesocotyl of the japonica type of rice usually did not elongate to more than $10 \mathrm{~mm}$ even in total darkness, although that of the indica type would elongate to more than $10 \mathrm{~mm}$.

Recently, in a rice cultivar of the japonica type it was found that the mesocotyl lengths of seedlings grown from imperfectly ripened grain were about 3 times longer than those grown from fully ripened grain (Inouye and Hibi, 1972). This result suggested that if immature rice grains of the japonica type are incubated, the mesocotyl may elongate as long as that of the indica type.

The mesocotyl lengths of seedlings grown in the dark in aseptic conditions were examined. The seedlings were grown from grains obtained at different stages of maturity after anthesis.

\section{MATERIALS AND METHODS}

The materials used were from four cultivars of paddy rice plants of the japonica type, Nihonbare, Norin-22, Saikai-112 and Reiho. The first and the second

*Present address; Toyama College of Technology, Toyama 
of these are early maturing varieties, and the third and the fourth are late maturing ones grown in the southern part of Japan. Plants were grown in pots (a/ 5000) under field conditions. All except the glumous flowers which were fertilized from the 3rd to the 5th day after the beginning of heading were cut off. About 30 grains were set on each panicle. Plants of a late maturing variety, Reiho, were then grown under controlled temperatures of 20,25 or $30{ }^{\circ} \mathrm{C}$ in a phytotron, and under field conditions, respectively. In the other three varieties, the plants were grown in a controlled temperature of $20^{\circ} \mathrm{C}$ and under field conditions. After $10,20,30,40$ or 50 days of these treatments, about 30 grains were obtained from each of the varieties and stored in an air conditioned room at $20{ }^{\circ} \mathrm{C}$ for further 50 days.

In order to examine the effect of $\mathrm{ABA}$ on the elongation of mesocotyl and coleoptile, Reiho was used as a material. In this experiment, seeds were obtained 50 days after anthesis under field conditions and stored in an air conditioned room at $20^{\circ} \mathrm{C}$ for about three months.

After removing the husk, the grain was disinfected in $75 \%$ alcohol for 30 $\mathrm{sec}$, then in $3 \%$ hydrogen peroxide for $3 \mathrm{~min}$ and finally washed one or two times with sterilized water. Unless otherwise mentioned, two grains were sown in a glass tube $(18 \times 250 \mathrm{~mm})$ containing about $6 \mathrm{ml}$ of $0.6 \%$ plain agar medium. The tubes were placed in the dark at a constant temperature of $30{ }^{\circ} \mathrm{C}$ for about 12 days. Each experimental treatment consisted of about 8 tubes.

\section{RESULTS AND DISCUSSION}

Effect of temperature during the development of the grain after anthesis on the mesocotyl and coleoptile elongations of the seedlings

Results obtained are given in Table 1 . The average mesocotyl length of seedlings grown from grains obtained at each temperature and 10-20 days after anthesis was greater than $10 \mathrm{~mm}$ with an exception for the grain obtained at 25 ${ }^{\circ} \mathrm{C}$ and 20 days after anthesis. Mesocotyl length decreased with maturity of the grain. On the other hand, the average coleoptile length increased with the maturity of the grain. Therefore, on an average, the total length of the seedling (length of the mesocotyl plus coleoptile) was similar for the grain harvested at different stages of maturity and at different temperatures.

Varietal differences in mesocotyl and coleoptile elongations of seedlings grown from grains at different stages of maturity

The results obtained at $20^{\circ} \mathrm{C}$ and under field conditions were almost the same in each variety. Therefore, varietal differences at $20{ }^{\circ} \mathrm{C}$ are shown in Table 2.

In an early and in two late maturing varieties, the average mesocotyl length of seedlings grown from grains obtained 10 and 20 days after anthesis was more than $10 \mathrm{~mm}$. In an early maturing variety, Nihonbare, the mesocotyl length was $16 \mathrm{~mm}$ even in the seedlings grown from grains obtained $\mathbf{3 0}$ days after anthesis. In the other early maturing variety, however, it was shorter than $10 \mathrm{~mm}$ in the seedlings grown from grains obtained 20 days after anthesis. In all the varieties 
Table 1. Effect of temperature during the development of the grains after anthesis on the mesocotyl and coleoptile elongations of the seedlings grown from this grain.

Mesocotyl (mm)

\begin{tabular}{|c|c|c|c|c|}
\hline \multirow{2}{*}{$\begin{array}{c}\text { Days after } \\
\text { anthesis }\end{array}$} & \multicolumn{4}{|c|}{ Temperature $\left({ }^{\circ} \mathrm{C}\right)^{*}$} \\
\hline & 20 & 25 & 30 & Field \\
\hline $\begin{array}{l}20 \\
30 \\
40\end{array}$ & $\begin{array}{l}\text { (2) } 65 \pm 39.7 \\
(10) 25 \pm 13.7 \\
(11) 5 \pm 1.4 \\
(15) 3 \pm 1.0\end{array}$ & 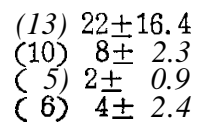 & $\begin{array}{cc}\text { (9) } & 16 \pm 12.2 \\
(5) & 14 \pm 1.7 \\
(4) & 5 \pm 2.7 \\
\text { (10) } & 7 \pm 3.1\end{array}$ & 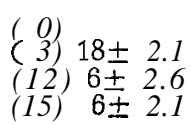 \\
\hline
\end{tabular}

Coleoptile ( $\mathrm{mm})$

\begin{tabular}{|c|c|c|c|c|}
\hline \multirow{2}{*}{$\begin{array}{c}\text { Days after } \\
\text { anthesis }\end{array}$} & \multicolumn{4}{|c|}{ Temperature $\left({ }^{\circ} \mathrm{C}\right)^{*}$} \\
\hline & 20 & 25 & 30 & Field \\
\hline $\begin{array}{l}10 \\
20 \\
30 \\
40\end{array}$ & $\begin{array}{rr}(2) & 4 \pm 1.4 \\
(10) & 18 \mathrm{ff} 9.5 \\
(11) & 24 \pm 6.3 \\
(15) & 34 \pm 7.3\end{array}$ & $\begin{array}{l}\text { (13) } 21 \pm 9.8 \\
\text { (10) } 30 \pm 9.9 \\
\text { (5) } 38 \mathrm{f} 1.7 \\
\text { (6) } 36 \pm 5.8\end{array}$ & $\begin{array}{ll}\text { ( 9) } & 22 \pm 13.7 \\
\text { (5) } & 29 \pm 14.3 \\
\text { (4) } 33 \pm 3.6 \\
\text { (10) } 37 \pm 3.3\end{array}$ & $\begin{array}{l}(0) \\
(3) \\
(12) \\
35 \pm 12.5 \\
\text { (15) } 40 \pm 6.5\end{array}$ \\
\hline
\end{tabular}

In each lot, fifteen seeds were sown and incubated at $30^{\circ} \mathrm{C}$ for 12 days in the dark.

The number of seedlings that grow is enclosed in parentheses.

*Temperatures during the development of the grains after anthesis.

Table 2. Varietal differences in mesocotyl and coleoptile elongations of seedlings grown from grains at different stages of maturity at $20^{\circ} \mathrm{C}$.

Mesocotyl (mm)

\begin{tabular}{|c|c|c|c|c|}
\hline \multirow{2}{*}{$\begin{array}{c}\text { Days after } \\
\text { anthesis }\end{array}$} & \multicolumn{4}{|c|}{ Varieties } \\
\hline & Nihonbare & Norin-22 & Saikai-112 & Reiho \\
\hline $\begin{array}{l}10 \\
20 \\
30 \\
40 \\
50\end{array}$ & 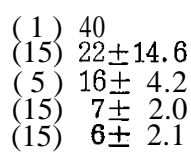 & $\begin{array}{ll}\text { (1) } & 30 \\
(14) & 8 \pm 3.3 \\
(15) & 6 \pm 3.0 \\
(13) & 4 \pm 1.3 \\
(15) & 3 \pm 1.8\end{array}$ & $\begin{array}{ll}(1) & 30 \\
(15) & 33 \pm 21.5 \\
4) & 4 \pm 1.6 \\
(15) & 5 \pm \\
(15) & 3 \pm 1.6 \\
\end{array}$ & $\begin{array}{rr}(2) & 65 \pm 39.7 \\
(10) & 25 \pm 13.7 \\
(11) & 5 \pm 1.4 \\
(15) & 3 \pm 1.0 \\
(15) & 2 \pm 1.0\end{array}$ \\
\hline
\end{tabular}

Coleoptile (mm)

\begin{tabular}{cc|c|c|c}
\hline Days after & \multicolumn{5}{|c}{ Varieties } \\
\cline { 2 - 6 } anthesis & Nihonbare & Norin-22 & Saikai-112 & Reiho \\
\hline 10 & $(1) 3$ & $(1) 3$ & $(1) 4$ & $(2) 4 \pm 1.4$ \\
20 & $(15) 14 \pm 8.6$ & $(14) 32 \pm 9.1$ & $(15) 10 \pm 4.8$ & $(10) 18 \mathrm{f} 9.5$ \\
30 & $(5) 1.9 \pm 6.4$ & $(15) 44 \pm 10.1$ & $(4 \mathrm{j}) 39 \pm 4.9$ & $(11) 24 \mathrm{f6} .3$ \\
40 & $(15) 26 \pm 2.7$ & $(13) 42 \pm 5.6$ & $(15) 43 \pm 13.3$ & $(15) 34 \pm 7.3$ \\
50 & $(15) 28 \pm 4.1$ & $(15) 47 \pm 10.4$ & $(15) 43 \pm 6.3$ & $(15) 39 \pm 7.4$ \\
\hline
\end{tabular}

In each lot, fifteen seeds were sown and incubated at $30^{\circ} \mathrm{C}$ for 12 days in the dark.

The number of seedlings that grow is enelosed in parentheses.

used in this experiment, the average mesocotyl length decreased with the maturity of the grain. On the other hand, the average length of the coleoptile increased with the maturity of the grain. Therefore, the average seedling length in each variety was nearly the same for grain of all stages of maturity. 


\section{Effect of $\mathrm{ABA}$ on the mesocotyl and coleoptile elongations of rice seedlings}

Recently, Takahashi $(1972,1973)$ found that ABA stimulated the elongation of mesocotyl to more than $\mathbf{2 0} \mathrm{mm}$ in a japonica type of paddy rice under darkness, though it inhibited the elongation of shoot above coleoptilar node. It seems that the morphological characters of these seedlings were similar to those of the seedlings grown from immature grains,

Two seeds were sown on medium contained of $0.6 \%$ agar and various concentrations of ABA (Sigma). Results are given in Table 3.

Table 3. Effect of ABA on the mesocotyl and coleoptile elongations in a paddy rice cultivar Reiho, japonica type.

\begin{tabular}{c|c|c|c}
\hline \multirow{2}{*}{$\begin{array}{c}\text { Concentrations } \\
\text { of ABA (ppm) }\end{array}$} & $\begin{array}{c}\text { Number of } \\
\text { seedlings }\end{array}$ & Mesocotyl & Coleoptile \\
\cline { 3 - 4 } & & $1 \pm 0.6$ & $24 \pm 3.5$ \\
Control & 18 & $1 \pm 0.4$ & $22 \pm 0.9$ \\
0.1 & 16 & $3 \pm 2.4$ & $17 \pm 4.3$ \\
0.25 & 17 & $15 \pm 10.9$ & $12 \pm 7.0$ \\
& 17 & $25 \mathrm{f} 12.9$ & $7 \pm 1.0$ \\
$\mathbf{0 . 5}$ & 16 & $17 \mathrm{t} 14.4$ & $7 \pm 2.2$ \\
1.0 & 17 & 0 & $3 \pm 1.0$ \\
2.5 & 17 & 0 & $3 \pm 0.9$ \\
$5: 0$ & & & \\
\hline
\end{tabular}

The average mesocotyl length of seedlings increased with concentration of $\mathrm{ABA}$ in the medium and it was longer than $10 \mathrm{~mm}$ in the medium which contained 0.25-1.0 ppm ABA. Against this, the average coleoptile length of seedlings decreased with the concentration of ABA. At the concentration of $0.5 \mathrm{ppm} \mathrm{ABA}$, the average mesocotyl length was at its maximum, whereas the average coleoptile length of seedlings was about one third times shorter than that of control ones. It seems that the morphological characters of these seedlings were similar to those of the seedlings grown from immature grains.

According to Oritani and Yoshida (1971), activity levels of ABA-like substances in rice grains were much higher in immature grains than those of fully ripened ones.

From the above results, it is suggested that ABA-like substances may be contained as stimulating factors in the mesocotyl of seedlings grown from immature grains in paddy rices of japonica type.

\section{REFERENCES}

Hamada, H. 1937 Physiologisch-systematische Untersuchungen über das Wachstum der Keimorgane von O ryza sativa L. Mem. Coll. Sci. Kyoto Imp. Univ., Series B, 12: 259-309

Inouye, J. and K. Hibi 1972 Studies on the emergence of rice seedlings in the direct sowing culture VI. Varietal difference in stimulation of mesocotyl elongation by high temperature treatment of seeds before sowing. Proc. Crop Sci. Soc. Japan, 41, : 73-77 (in Japanese) 
Kato, S. 1930 On the affinity of the cultivated varieties of rice plants, O ryza sativa L. Jour. Dept. Agr. Kyushu Imp. Univ., 2: 241-276

Kato. S., H. Kosaka and S. Hara 1928 On the affinity of rice varieties as shown by the fertility of hybrid plant. Rep. Bul. Sci. Fakult. Terkult. Kjusu Imp. Univ., 3: 132-147 (in Japanese)

Oritani, T. and R. Yoshida 1971 Studies on nitrogen metabolism in crop plants XI. The changes of abscisic acid and cytokinin-like activity accompanying with growth and senescence in the crop plants. Proc. Crop Sci. Soc. Japan, 40: 325-331

Takahashi, K. 1972 Abscisic acid as a stimulator for rice mesocotyl growth. Nature New Biol., 238 (81) : 92-93

Takahashi, K. 1973 Interaction between ethylene, abscisic acid and gibberellic acid in elongation of rice mesocotyl. Planta, 103: 363-364 